Universidad de Lima

Facultad de Derecho

Carrera de Derecho

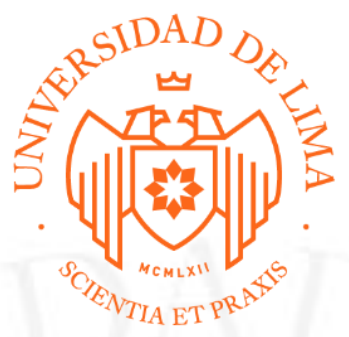

\title{
ARBITRAJE: "ARBITRAJE" Y REGISTRAL: "REGISTRAL"
}

Trabajo de suficiencia profesional para optar el Título Profesional de Abogado

\section{Rivera Albuquerque, Nicoll Arlett}

Código 20121099

$$
\text { Lima - Perú }
$$

Setiembre de 2019 
Materia: Arbitraje

$\mathrm{N}^{\circ}$ de Expediente: 2174-201-2011

El presente caso gira en torno a la controversia surgida entre una unidad pública y una entidad privada en mérito de un contrato de compraventa, la cual es revisada en un procedimiento arbitral. Se analiza la figura del incumplimiento, de conformidad, resolución y penalidades.

Por tales elementos, el caso está relacionado con las ramas del derecho administrativo, derecho civil y derecho arbitral.

Materia: Registral

$\mathrm{N}^{\circ}$ de Expediente: 2008-000776320

El caso se refiere a una controversia entre la Asociación Civil LAVC y la Superintendencia Nacional de los Registros Públicos, por el error de inscribir incorrectamente el nombre de la asociación 